\title{
Two new species of Phyllanthus and notes on Phyllanthus and Sauropus (Euphorbiaceae: Phyllantheae) in New South Wales
}

\author{
John T. Hunter and Jeremy J. Bruhl
}

\begin{abstract}
Hunter, J.T. and Bruhl, J.J. (Department of Botany, University of New England, Armidale, NSW 2351, Australia) 1997. Two new species of Phyllanthus and notes on Phyllanthus and Sauropus (Euphorbiaceae: Phyllantheae) in New South Wales. Telopea 7(2): 149-165. Descriptions of two new species of Phyllanthus (P. involutus J.T. Hunter \& J.J. Bruhl and P. occidentalis J.T. Hunter \& J.J. Bruhl) from New South Wales are presented, together with descriptions and notes on other New South Wales species of Phyllanthus and of Sauropus.
\end{abstract}

\section{Introduction}

The Phyllantheae, in particular Phyllanthus and Sauropus, have presented considerable taxonomic problems within Australia. Webster (1956) compared the Phyllantheae to '... political boundaries which are superposed over the natural physiographic features of a region.' He added that Phyllanthus was essentially the place where species were put when they did not fit into any of the other genera in the Phyllantheae.

This paper aims to clarify the status of the New South Wales species of Phyllanthus and Sauropus. Two new species recognised in the current Flora of Australia investigation have their distributions predominantly within New South Wales, and full descriptions of these species are presented here. Additionally, an update is presented of the descriptions, distributions and nomenclature for the New South Wales species of these genera (cf. James \& Harden 1990).

\section{Methods}

Sampling and organisation of data: significant proportions of the Phyllanthus specimens held by the herbaria AD, BRI, CANB, DNA, HO, MEL, NSW, PERTH and QRS, and historically important Phyllanthus specimens from A and GH were provisionally sorted into taxa. Close inspection of these taxa and subsequent re-sorting of specimens formed the basis for our decisions on the status of these taxa. Ten representative specimens (where available) of these taxa were chosen for detailed analysis of quantitative micromorphological characters. Macromorphological characters (qualitative and quantitative; e.g., leaf length) were scored in all available material. Selection of the ten specimens for study was based on specimen quality in terms of the amount and number of developmental stages displayed.

A DELTA (Dallwitz 1980; Dallwitz et al. 1993) list of 395 characters and their states has been created by the authors for the Phyllantheae (Bruhl \& Hunter unpublished). This was used to score attributes measured in selected specimens, together with those measured in all available material. 
Fresh material was used where possible, but in most instances floral measurements were based on re-hydrated material. Mature leaves only were used for scoring leaf characters.

Terminology: for purposes of consistency across the members of the Phyllantheae, the perianth segments of Phyllanthus and Sauropus are referred to as sepals. Further developmental investigations need to be carried out to confirm this interpretation (Webster pers. comm. 1993).

Terminology for seed surface characters follows that of Stearn (1992). A bordered hilum is one rimmed by a discoloured and often raised region. This character is most obvious in Phyllanthus fuernrohrii F. Muell. (see Hunter \& Bruhl 1996, Fig. 1A, C).

There are sometimes differences between the leaves of branches, referred to as 'branch leaves', and those on ultimate branchlets referred to as 'branchlet leaves'. Phyllanthoid branching is indicated by a reduction of the leaf that subtends a branch/branchlet to a scale-like structure, as illustrated by Webster (1970). Branch leaves exhibiting intermediate reduction in size, but still clearly laminate, are referred to as 'reduced'. Care should be taken, where leaves may have fallen, to check for a leaf scar which will always be present.

Citation: type specimens of all relevant names have been seen by one or both of the authors, unless otherwise indicated by 'n.v.'. Photographs of most of the type specimens examined at $\mathrm{BM}$ and $\mathrm{K}$ are held at $\mathrm{NE}$, together with photographs taken of type specimens on loan to NE.

Locality statements are direct quotations from labels and are unmodified.

A list of all specimens studied will be deposited at NE. An INTKEY dataset for interactive identification will be made available on completion of our study of the Australian Phyllantheae.

\section{Taxonomy}

\section{Phyllanthus}

1a. Phyllanthus amarus Schum., Beskrivn. Guin. Pl.: 421 (1827).

P. niruri var. armarus (Schum.) Leandri, Flore Madagascar 111: 73 (1958).

Type: 'Guinea', Schumacher E Thonning s.n. (holo C, n.v., fide Webster 1970: 69).

Illustration: Webster, Brittonia 22: 46, 47 (1970); Wheeler in J.R. Wheeler (ed.), Flora of the Kimberley Region: 621, fig. 190A \& 623, 191A (1992).

Distribution: Phyllanthus amarus is naturalised in Australia, where it has a very sporadic distribution. It occurs more commonly in tropical regions from the Ord River in Western Australia across the north to the Torres Strait Islands, but extends as far south as Sydney (Fig. 1). The species is native to the Americas, but is now a pantropical weed (Webster 1970; Airy Shaw 1980).

Notes: P. amarus appears to be restricted to highly disturbed areas within Australia and are often found in lawns and gardens. This species is known to occur in sugar cane crops, but poses no threat to this crop. The earliest known collections of this plant in Australia is from Darwin in 1883 (MEL: Holtze 291, 374 'Port Darwin 1883'). 
1b. Phyllanthus carpentariae Muell. Arg., Linnaea 34: 72 (1865).

Type: Northern Territory: 'Tableland ad Sinum Carpentariae', 'Jul 1856 1863', F. Mueller s.n. (holo G-DC; ?iso MEL n.v.); 'Roper River ex Nat. Herb.' F. Mueller s.n. (probable iso BRI (fragment: AQ342649)); 'Tableland, Arnhems Land, Roper River', F. Mueller s.n. (probable iso K).

Phyllanthus grandisepalus Muell. Arg., Linnaea 34: 72 (1865).

Type: Northern Territory: Fitzmaurice River, Arhemland [as 'Fitzmourice-River'], 1863 Ferd. Mueller s.n. (holo G-DC; iso K, ?MEL n.v.).

Phyllanthus hebecarpus Benth., Flora Australiensis 6: 108 (1873).

Type: Northern Australia: 'Gulf of Carpentaria', F. Mueller s.n. (syn K, MEL n.v.); 'Burdekin River' F. Mueller s.n. (probable syn K, MEL n.v.)

Phyllanthus fuernrohrii var. suffruticosus Domin, Beiträge zur Flora Pflanzengeographie Australiens: 875 (1927) in Bibliotheca Botanica 89, 22: 321 (1927).

Type: 'Queensland: Castle Hill bei Townsville', Feb 1910, Domin s.n. (probably PR, n.v.).

Illustration: James \& Harden in G.J. Harden (ed.), Flora of New South Wales 1: 396 (1990) as P. hebecarpus; Dunlop et al.; Flora of the Darwin Region 2: 232, fig. 75 (1995) as P. grandisepalus.

Distribution: known from Darwin to Groote Eylandt in the Northern Territory, round the Gulf of Carpentaria and south through central and coastal Queensland to Gunnedah in New South Wales. Occurring in a variety of habitats. The palatability of

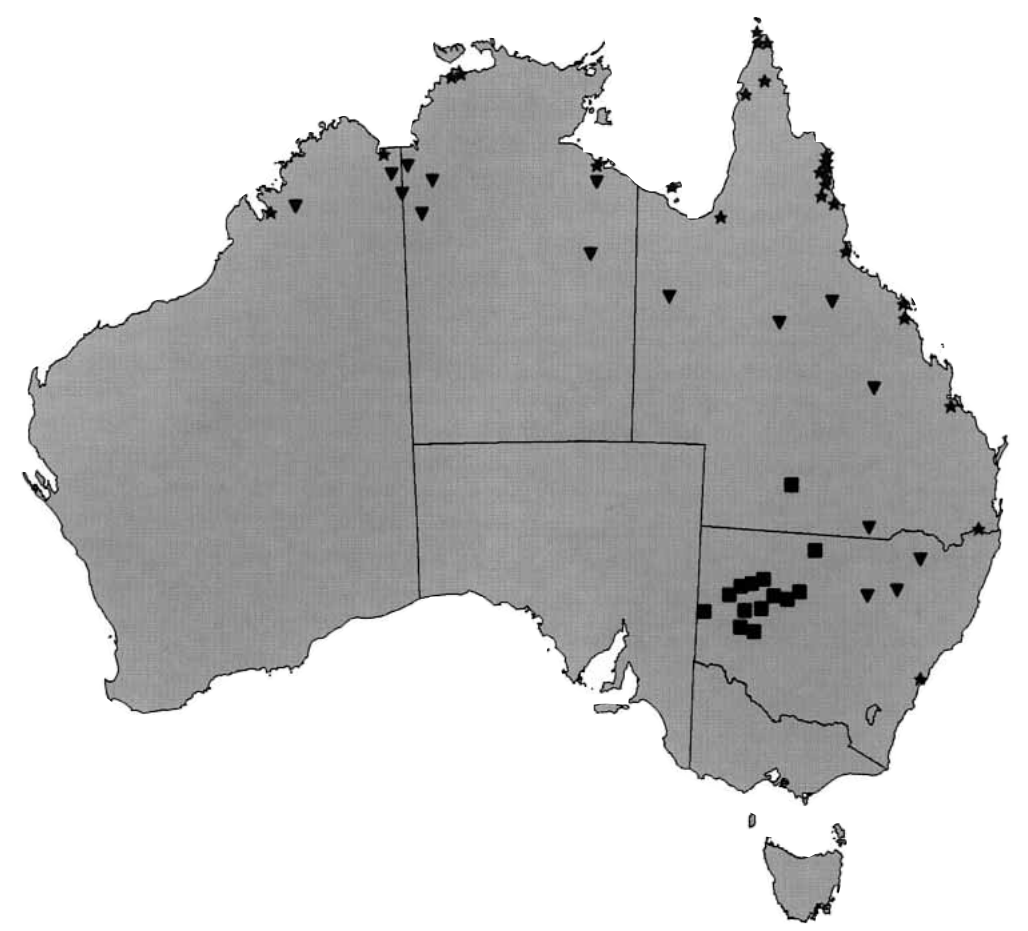

Fig. 1. Distribution of Phyllanthus amarus within Australia $\otimes$, P. lacerosus $₫$, and P. involutus $\bowtie$. 
P. carpentariae is unknown, but L. Bancroft (12 November 1964, AQ 057283 (BRI)) noted that plants were 'Not grazed by cattle.'

Notes: no constantly distinct characters could be found to separate Phyllanthus grandisepalus, $P$. hebecarpus or $P$. carpentariae. Therefore, these species have been included within $P$. carpentariae. The main differences within and between populations appears to be the density of indumentum and the length of the trichomes on the leaves and stems.

1c. Phyllanthus gunnii Hook. f., Hook. Lond. Journ. Bot. 6: 284 (1847).

Type: [Tasmania], 'Circular Head and George Town': Circular Head, 13 Nov 1837 and 13 Dec 1837, Gunn s.n. (syn K, BM); George Town, 29 Jan 1843, Gunn s.n. (syn K, BM).

Phyllanthus gasstroemii Muell. Arg., Linnaea 32: 17 (1863).

Type: New South Wales: [New South Wales] 'In Nova Hollandia ad Botany-Bay', Casstroem s.n. as 'Gasstroem [sic] in hb. holm' (type unknown, ?UPS).

Illustrations: Cochrane et al., Flowers and Plants of Victoria: 102, fig. 298 (1968); Rotherham et al., Flowers and Plants of New South Wales and Southern Queensland: 84, fig. 249 (1975) as P. gasstroemii; Cunningham et al., Plants of Western New South Wales: 460 (1981); Beadle, Students Flora of North Eastern New South Wales 3: 308, fig. 143E (1982) as P. gasstroemii; Stanley in T.D. Stanley \& E.M. Ross, Flora of South-eastern Queensland 1: 430, fig. $67 \mathrm{H}(1983)$ as P. gasstroemii; Fairley \& Moore, Native Plants of the Sydney District: 100, fig. 276 (1989) as P. gasstroemii; James \& Harden in G.J. Harden (ed.) Flora of New South Wales 1: 397 (1990) as P. gunnii and P. gasstroemii; Costermans, Native Trees and Shrubs of South-Eastern Australia: 209 (1991); Robinson, Field Guide to the Native Plants of Sydney: 168 (1991); Howell et al., Riverside Plants of the Hawkesbury-Nepean: 51 (1995).

Notes: Phyllanthus gasstroemii is treated here as within the variability of P. gunnii. Phyllanthus gasstroemii has been distinguished from $P$. gunnii on the basis of minor differences in leaf shape, the number of flowers per axillary inflorescence, and the extent of fusion of the staminal filaments in the male flowers (see Bentham 1873; James \& Harden 1990). Leaf shape is variable in both entities, and their states largely overlap. The number of flowers per inflorescence is also highly variable and does not help to distinguish these two species. The character most commonly used to separate the species in keys, the extent of staminal filament fusion, is not constant for the species. The type specimen of P. gunnii exhibits all states from free to completely fused filaments. Further, both occur in similar habitats.

In general, the northern populations of this taxon have been most commonly called $P$. gasstroemii and the southern populations P. gunnii. No attributes were found during this study that supported the recognition of P. gasstroemii as distinct from P. gunnii. A detailed population study of this complex is warranted, meanwhile we include P. gasstroemii within P. gunnii.

Phyllanthus saxosus F. Muell., while predominantly a South Australian species, merits discussion here. This species, described in 1853, was ten years later reduced to varietal status as P. gunnii var. saxosus (F. Muell.) Muell.Arg. Although there are only a few attributes that separate $P$. saxosus from $P$. gunnii, these provide stable and distinct differences supporting the former's recognition at the rank of species. Plants of $P$. saxosus are dioecious, have papillate leaves (Weber 1986), and are restricted to South Australia. Plants of P. gunnii are monoecious, have epapillate leaves (see also Weber 1986; James \& Harden 1990), and occur in eastern Australia (Figure 4). 
1d. Phyllanthus hirtellus F. Muell. ex Muell. Arg., Linnaea 32: 22 (1863).

P. hirtellus var. hirtellus Muell. Arg., Linnaea 32: 22 (1863). P. thymoides var. hirtellus (Muell. Arg.) Muell. Arg. in DC., Prodomus 15(2): 372 (1866).

Type: [Australia], 'In Nova-Hollandia' F. Mueller s.n. (syn G-DC), Mitchell s.n. (syn ‘hb. berol.' n.v.) .

Phyllanthus hirtellus var. ledifolius Muell. Arg., Linnaea 32: 22 (1863).

Phyllanthus thymoides var. ledifolius (Muell. Arg.) Muell. Arg. in DC., Prodromus 15(2): 372 (1866).

Type: 'N.S. Wales', 1836, A. Cunningham 115,. (holo G-DC).

Phyllanthus hirtellus var. thymoides Muell. Arg., Linnaea 32: 22 (1863).

Phyllanthus thymoides (Muell. Arg.) Muell. Arg. in DC., Prodromus 15(2): 372 (1866).

Type: [New South Wales], 'Ad Port-Jackson', 1825, Sieber 264 (syn G-DC, K, MEL); 'Gaudich.' (syn probably G-DC n.v.); 'Cunningh.' (syn probably G-DC n.v.).

Phyllanthus thymoides var. glabratus Muell. Arg. in DC., Prodromus 15(2): (1866: 372); Benth., Flora Australiensis 6: 109 (1873) as 'glabrata'.

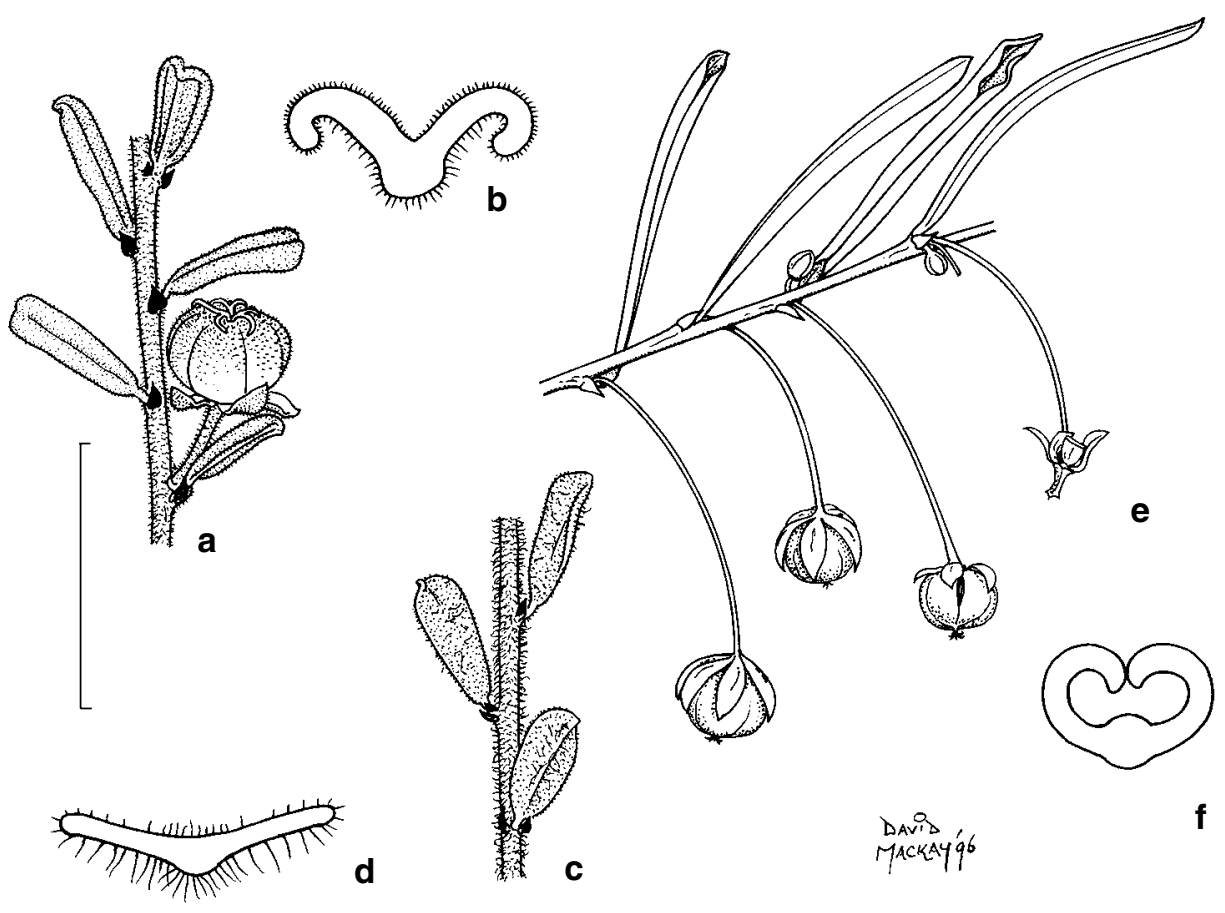

Fig. 2. a \& b: Phyllanthus occidentalis. a, habit; b, mid-leaf trans-section; c \& d: P. hirtellus. c, habit; d, mid-leaf trans-section; e \& f: P. involutus. e, habit; $\mathbf{f}$, mid-leaf trans-section. a \& b from Norris 852 $\mathcal{E}$ Thomas (NSW); c \& d from Phillips 369 (CBG); e \& f from Wasson s.n. (NSW 248780). Scale bar: $\mathrm{a}, \mathrm{c} \& \mathrm{e}=1 \mathrm{~cm} ; \mathrm{b}, \mathrm{d} \& \mathrm{f}=2 \mathrm{~mm}$. 
Type: [New South Wales], Twofold Bay [as 'Tevofold-Bay' in the Prodromus], 1863, F. Mueller s.n., (holo G-DC; probable iso K, MEL, two sheets, one with 'Sep').

Phyllanthus thymoides var. parviflorus J. M. Black, Flora of South Australia 2: 352 (1924); Phyllanthus hirtellus var. parviflorus (J. M. Black) H. Eichler, Supplement to J.M. Black's Flora of South Australia, edn 2, 209 (1965).

Type citation: 'Near Wolseley. - Victoria; New South Wales'.

Type: Tatiara, J.T. Woods s.n. (fragment AD, 'Nat. Herb. Vict.' (AD 98438075))

Illustrations: Rotherham et al., Flowers and Plants of New South Wales and Southern Queensland: 73, fig. 209 (1975) red flowered form, as P. thymoides; Fairley \& Moore, Native Plants of the Sydney District: 100, fig. 277 (1989) as P. thymoides; James \& Harden in G.J. Harden (ed.), Flora of New South Wales 1: 396 (1990) as P. hirtellus forma A; Robinson, Field Guide to the Native Plants of Sydney: 168, Fig. 4c-d (1991).

Distribution: Phyllanthus hirtellus occurs in mainland south eastern Australia generally on and east of the Great Divide, from Lismore on the north coast of New South Wales to the Grampians in Victoria (Fig. 3). Minor extensions of distribution into the Central Western Slopes district of New South Wales also occur.

Notes: Mueller Argoviensis cited three specimens in the Prodromus for P. thymoides var. hirtellus one, 'interiore Novae-Hollandiae (Mitchell! in hb. berol.)', is a syntype for the earlier name Phyllanthus hirtellus Muell. Arg. The other two specimens are considered to have no type status. These are G-DC specimens labelled as follows: 'Nov. Holland. meridonal. Mount Hunter. Plantae Muellerianae' and 'Macallister River. F. Muell. 1863'. We have seen a further three MEL sheets that are probably duplicates of the latter specimens, viz. MEL 1594841: 'Mount Hunter Wilsons promontory' and 'Wilsons

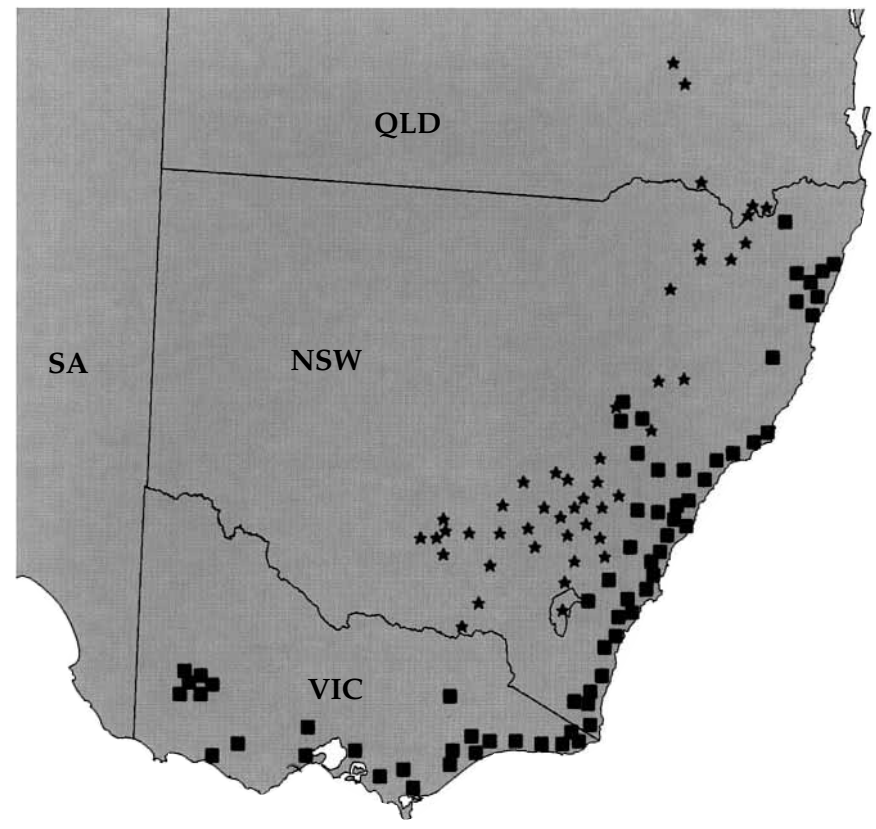

Fig. 3. Distribution of Phyllanthus hirtellus $\bowtie$ and P. occidentalis $\bowtie$. 
promontory'; MEL 1594850: ‘ ... Mountain Hunter. 11 May '53'; MEL 1594838: 'Mountains on the M'Allister River'.

We interpret Bentham's (1873) name Phyllanthus thymoides var. 'glabrata' as an orthographic variant of $P$. thymoides var. glabratus Muell. Arg. (see above). Bentham (1873) cited two specimens, one is a syntype of this variety (viz.: Twofold Bay, F. Mueller s.n.), and the other specimen is a topotype (Twofold Bay, Mossman s.n., n.v.), but not a syntype.

Some flora treatments (Moore \& Betche 1893; Beadle 1976; Stanley 1983) have used the incorrect name $P$. thymoides instead of $P$. hirtellus var. thymoides.

We have not detected morphological variants within $P$. hirtellus that are worthy of recognition.

Phyllanthus hirtellus is known from wet sclerophyll forest, swamp sclerophyll forest, dry sclerophyll forest, grassy woodland, dry sclerophyll woodland and coastal and montane heath at altitudes up to $1,100 \mathrm{~m}$. The most northern near-coastal populations at Lismore approach morphologically, but are distinct from, an undescribed Queensland species (Hunter and Bruhl in prep.) that has longer leaves and antrorse indumentum. P. hirtellus is morphologically most similar to P. occidentalis J.T. Hunter \& J.J. Bruhl (Table 1).

A form of P. hirtellus with red male flowers occurs in a band across northern Sydney from Wollemi and the lower Blue Mountains in the north and west to the Hawkesbury area in the north-east.

\section{1e. Phyllanthus involutus J.T. Hunter \& J.J. Bruhl, sp. nov.}

A congeneribus foliis involutis et $P$. exili $S$. Moore affini foliis majoribus et fructibus laevibus non tuberculatis differt.

Type: New South Wales: Belaraboon Range, c. 100 km SW of Cobar, Wasson NSW 248780, 1971 (holo NSW).

Phyllanthus sp., Cunningham et al., Plants of Western New South Wales: 463 (1981). Phyllanthus sp. B, Jacobs \& Pickard, Plants of New South Wales: 117 (1981); James \& Harden in G.J. Harden, Flora of New South Wales 1: 398 (1990).

[Phyllanthus subcrenulatus auct. non F. Muell., A. Morris, Plantlife of the West Darling: 70 (1966)]

Illustration: Cunningham et al., Plants of Western New South Wales: 464 (1981) as 'hill spurge'; James \& Harden in G.J. Harden, Flora of New South Wales 1: 398 (1990) as Phyllanthus sp. B.

Monoecious perennial shrub, 0.4-1 m tall. Branchlets persistent, rounded, $7-20 \mathrm{~cm}$ long, 0.4-0.7 mm wide, glabrous. Stipules persistent, free, triangular, 1.2-2.6 mm long, cream to red-brown; bases truncate to cordate; apices acuminate to acute, chartaceous, entire or dentate, glabrous. Leaves alternate, distichous, brown when dry or remaining green; petioles $0.5-1.3 \mathrm{~mm}$ long, $0.2-0.6 \mathrm{~mm}$ wide, glabrous; laminae concave, linear to lanceolate or almost terete, $11.4-26.8 \mathrm{~mm}$ long, 0.6-3.8 mm wide, light-green in colour, sub-coriaceous, obscurely pinnately veined, glabrous; bases symmetrical, rounded, obtuse to cuneate; apices erect, acuminate to obtuse, mucronate; margins involute. Inflorescences at least sometimes with the sexes mixed, axillary, sessile. Bracts and bracteoles present, deciduous. Male flowers solitary; pedicels 0.4-2 mm long, glabrous; sepals free, 6, ovate, $0.8-2.1 \mathrm{~mm}$ long, 0.1-1.6 mm wide, white to yellow-brown in colour, obtuse to acute, sometimes mucronate, entire, membranous to chartaceous, glabrous; disk of 6 discrete discs, 0.6-1.1 mm wide; stamens 3, 1-whorled, 
symmetrical, erect; filaments connate from much more than half their length to fully connate, erect, terete, 0.2-0.5 mm long; anthers extrorse, erect, oblong, 0.3-0.5 mm long; locules parallel. Female flowers one in each axil, with one male flower when mature; pedicels at anthesis 3-7 mm long, 0.1-0.3 mm wide, in fruit 3.5-11.1 mm long, glabrous; sepals free, 6, ovate, $1.3-3 \mathrm{~mm}$ long, $0.7-1.5 \mathrm{~mm}$ wide, white to yellowbrown in colour, with a distinct white margin, obtuse to acute, coriaceous, glabrous, midrib raised; disk lobes crenate, $0.7-1.4 \mathrm{~mm}$ wide; styles 3 , free, divided for half their length or less, erect to divergent, pink to red in colour, narrow-terete, $0.4-0.8 \mathrm{~mm}$ long, 0.1-0.3 mm wide, glabrous, with branches entire or rarely bifid, linear; ovary $0.5-1.2 \mathrm{~mm}$ long, 0.7-1.8 mm wide, transversely ellipsoid, apically depressed, smooth, glabrous. Fruit a capsule, septicidal, transversely ellipsoid, apically depressed, 2-3 $\mathrm{mm}$ long, 3.2-4.6 mm wide, yellow-brown to green in colour, cartilaginous, smooth and glabrous; column persistent, $0.9-1.5 \mathrm{~mm}$ long. Seeds yellow or black with age, lenticular to prismatic, laterally compressed, $1.8-2.2 \mathrm{~mm}$ long, $1.3-1.5 \mathrm{~mm}$ wide, smooth; hilum markedly depressed, sometimes slightly discoloured around the margin, ovate, with cavity basal and sometimes displaced. Flowering: March to December. Fruiting: March to December. Fig. 2e, f.

Selected specimens: Queensland: Warrego District: On rock near Globe Mine, Morris s.n., Sep 1919 (AD).

New South Wales: Far North Western Plains: Broken Hill, Morris s.n., Aug 1921 (AD); 'Tongo', Paroo River, West Darling, Hitchcock s.n., 1970 (NSW); 23 km N of Barrier Highway on Tilpa Rd, Cunningham and Milthorpe 961, Aug 1973 (NSW); North Western Plains: 3 km N. Ledknapper Crossing [to] Nulty Springs, Cunningham and Milthorpe 4158, 20 Nov 1975 (NSW); Mt. Grenfell, c. $40 \mathrm{~km}$ NW of Cobar, Cunningham and Milthorpe 930, 13 Aug 1973 (NSW). South Far Western Plains: Mt Manara, SH21-38 miles N of Ivanhoe, Whaite \& Whaite 2098, 10 Nov 1956 (NSW); Mt Manara, Henshall s.n., 19 Nov 1972 (NSW).

Distribution: this species has an infrequent and scattered occurrence in the Western and Far Western Plains of New South Wales from Cobar to Broken Hill, with two collections from south-western Queensland (Fig. 1).

Notes: Phyllanthus involutus is known to occur in mallee, grassy woodland and temperate and tussock grasslands on sandstone and quartzite ridges and hills amongst rocks and along intermittently flowing creeks. Many collections by Albert Morris (e.g., Aug 1921, Morris s.n. (AD96824222); Sep 1919, Morris s.n. (AD98663187)) have been mis-labelled as $P$. subcrenulatus F. Muell. Very few collections of $P$. involutus are available in herbaria, although apparently it is common where it is found growing. This species should be considered rare, especially in Queensland where only two collections are known. We suggest an initial conservation coding of 3RC-QN (Briggs \& Leigh 1996).

\section{1f. Phyllanthus lacerosus Airy Shaw, Kew Bull. 35: 386 (1980).}

Type: Northern Territory: Negri-Stirling area, $17^{\circ} 10^{\prime}$ S, $129^{\circ} 15^{\prime}$ E, black clay plain, Dunlop 3567, 3 May 1974 (holo K; iso DNA n.v., NSW).

[Phyllanthus maderaspatanus [sic] var. angustifolius auct. non Benth.; Forster \& Henderson (1994: 115) p.p..]

[Phyllanthus maderaspatensis auct. non L.; Dunlop et al., Flora of the Darwin Region 2: 231 (1995), p.p.]

Phyllanthus sp. A, James \& Harden in G.J. Harden (ed.), Flora of New South Wales 1: 397 (1990).

Phyllanthus sp. A, Wheeler in J.R. Wheeler, Flora of the Kimberley Region: 623 (1992). 
Illustrations: James and Harden in G.J. Harden (ed.), Flora of New South Wales 1: 397 (1990); Wheeler in J.R. Wheeler, Flora of the Kimberley Region: 621, fig. 190H, 623 fig. $191 \mathrm{H}$ (1992), both as P. sp. A.

Distribution: The distribution of P. lacerosus is extensive but sporadic. It is known from the Kimberley in Western Australia through the Northern Territory and central Queensland to as far south as Narrabri on the North Western Slopes of New South Wales (Figure 1). Phyllanthus lacerosus occurs in tropical or temperate grasslands, apparently exclusively on black cracking-clay soils.

Notes: Airy Shaw (1980) published a valid name for this species; however, it apparently has not been used in Australia except for a few specimens annotated by him as such. Both James and Harden (1990) and Wheeler (1992) referred to this species as Phyllanthus sp. A.

Phyllanthus lacerosus is endemic to Australia though Wheeler (1992) suggested that it may be an introduced weed as it was found in irrigation fields of Kununurra. This species may be mistaken for P. maderaspatensis, but can be distinguished from that by the free not fused staminal filaments, deeply divided not barely notched styles and striate not colliculose seeds. In most herbaria, collections of $P$. lacerosus have been identified as $P$. maderaspatensis, usually as P. maderaspatanus var. angustifolius. Authors in some Floras (e.g. Dunlop et al. 1995) have widened the circumscription of $P$. maderaspatensis to include the morphological variation that we recognise as P. lacerosus.

A specimen from Leichhardt District (Capella, B. Smith s.n. (BRI, AD 440662)) is labelled: 'Weed resistant to 2,4-D.'

1g. Phyllanthus maderaspatensis L., Sp. Pl. 982 (1753).

Notes: Bentham (1873), Ewart \& Davies (1917) and James and Harden (1990) have all used the incorrect spelling $P$. maderaspatanus for the name of this species.

1h. Phyllanthus oblanceolatus J.T. Hunter \& J.J. Bruhl, J. Adel. Bot. Gard. 17: 127-136 (1996).

Notes: This recently described species has its main distribution within South Australia and the Northern Territory. Collections from within New South Wales have come from near Cobar and the Barrier Range. A full description of this species is given elsewhere by Hunter and Bruhl (1996).

1i. Phyllanthus occidentalis J.T. Hunter \& J.J. Bruhl, sp. nov.

Similis P. hirtello F. Muell. ex Muell. Arg., a qua foliis hirtioribus marginibus recurvatis vel revolutis non complanatis plerumque angustioribus (0.5-3.4 non 1.8-6.6 mm latis) differt.

Types: New South Wales: South Western Plains: Mt Bunganbil, NE of Griffith, Norris $\mathcal{E}$ Thomas 852, Mar 1987 (male specimen) (holo NSW).

Phyllanthus hirtellus Muell. Arg. forma B; James \& Harden in G.J. Harden (ed.) Flora of New South Wales 1: 396 (1990).

[Phyllanthus thymoides auct. non (Muell. Arg.) Muell. Arg.; Stanley in T.D. Stanley \& E.M. Ross, Flora of South-eastern Queensland 1: 428 (1983); Forster \& Henderson, Queensland Vascular Plants: Names E Distribution 116 (1993); McDonald et al., The Flora of Girraween and Bald Rock National Parks: 78 (1995), p.p.] 
Illustrations: Cunningham et al., Plants of Western New South Wales: 463 (1981) as Thyme Spurge; James \& Harden in G.J. Harden (ed.) Flora of New South Wales 1: 396 (1990) as P. hirtellus forma B.

Dioecious perennial compact shrub $0.2-1 \mathrm{~m}$ tall. Branchlets rounded, 6-21.5 cm long, 0.5-1.1 mm wide, scabrous, puberulous to pilose. Stipules persistent, free, ovate to depressed-ovate, $0.5-1.6 \mathrm{~mm}$ long, red to black, scabrous to puberulous; bases rounded to obtuse or cordate; apices acuminate to acute; margins entire. Leaves alternate, distichous; petioles $0.3-1 \mathrm{~mm}$ long, $0.2-0.6 \mathrm{~mm}$ wide, indumented; laminae convex, elliptical, oblong, obovate to oblanceolate, 4-8.5 mm long, 0.5-3.4 $\mathrm{mm}$ wide, mid-green, paler below or with both sides of equal intensity, obscurely veined, puberulous to pubescent and sometimes with scattered pilose hairs or rarely densely scabrous, indumentum seemingly longer and denser on abaxial surface; bases rounded to obtuse; apices erect, acuminate to acute or obtuse to obcordate, often with the tip down-turned, mucronate; margins recurved to strongly revolute and thickened. Bracts and bracteoles deciduous, indumented. Inflorescences axillary, sessile. Male flowers 1-4 per cluster; pedicels 0.7-2.8 mm long, indumented; sepals 6, elliptical, ovate, trullate or obtrullate, obtuse to acute, $0.9-2.4 \mathrm{~mm}$ long, $0.7-2.2 \mathrm{~mm}$ wide, white to yellow in colour, chartaceous, abaxially (rarely adaxially) puberulous, pubescent or pilose; disk comprising 6 discrete lobes, $0.9-2.1 \mathrm{~mm}$ wide; stamens 3 , erect to declinate; filaments variously connate, erect, terete, $0.5-1.5 \mathrm{~mm}$ long in total; anthers extrorse, ascending to divaricate, oblong, elliptical or circular in outline, 0.3-0.6 mm long, locules parallel to divergent. Female flowers 1 or 2 per cluster; pedicels at anthesis 0.7-2.2 mm long, $0.2-0.5 \mathrm{~mm}$ wide, in fruit $1.8-3.5 \mathrm{~mm}$ long, $0.2-0.5 \mathrm{~mm}$, indumented; sepals free, 6, circular, ovate, trullate or hastate, $0.7-2.3 \mathrm{~mm}$ long, $0.6-2 \mathrm{~mm}$ wide, white to yellow or green in colour, obtuse to acute, coriaceous, abaxially and more rarely adaxially puberulous, pubescent or pilose; disk lobes crenate, 1.1-2.5 mm wide; styles 3 , free, variously divided, ascending to divergent, narrow-terete but often with the base swollen, sometimes pilose on the swollen base, 0.3-1.6 mm long, 0.1-0.4 mm wide, branches entire, linear; ovary transversely ellipsoid and apically depressed, 0.5-1.2 mm long, 0.7-1.7 mm wide, smooth, pubescent. Fruit a capsule, septicidal, explosive, transversely ellipsoid, apically depressed, $1.5-2.4 \mathrm{~mm}$ long, $2.5-4.2 \mathrm{~mm}$ wide, yellow-brown to grey in colour, cartilaginous, smooth, puberulous to pubescent, grooved septicidally; column persistent, narrow oblong, 0.9-1.7 mm long. Seeds prismatic, laterally compressed, $1.4-2.2 \mathrm{~mm}$ long, $0.9-1.8 \mathrm{~mm}$ wide, smooth or scalariform, red-brown, purple to black; hilum circular and elliptic, slightly depressed and sometimes with the border lighter in colour, with cavity basal. Flowering: All year. Fruiting: September to March. Fig. 2a, b.

Selected specimens: Queensland: Darling Downs District: Barakula State Forest, Williams 84169, 3 Oct 1984 (BRI).

New South Wales: Central Tablelands: Orange District, Madsen s.n. , Nov 1949 (NSW). Southern Tablelands: Queanbeyan, Burgess s.n., 13 Oct 1962 (CBG); Black Mtn near dam on south east slope, Hain 72, 26 Sep 1975 (CBG). North Western Slopes: 2 km W of Goolgowi-Rankin Springs Rd, Mulham 1185, 1 Sep 1977 (NSW). Central Western Slopes: Harvey Ranges, Peak Hill, Boorman s.n., Nov 1905 (NSW); Weddin Range, 16 km north of Bimbi, Grenfell, Sikkes AS513, 1 Nov 1973 (CBG). South Western Plains: Mt Bunganbil, north-east of Griffith, Norris \& Thomas 852, 1 Oct 1978 (NSW: female branch in type folder); near Griffith, Cocoparra National Park, north face of Mt Caley, Butler 749, 17 May 1989 (CBG); Cocoparra Range, north of Yenda, Bates 18303 (AD).

Distribution: Phyllanthus occidentalis is widespread and abundant on the western side of the Great Divide. It is known from the Western Slopes and the western edge of the Tablelands in New South Wales, and the Darling Downs District of Queensland (Fig. 3). 
Notes: the holotype is the male specimen tagged 'Holotype of Phyllanthus occidentalis J.T. Hunter \& J.J. Bruhl'. There are two further branches loose on the sheet (one male and one female) and considerable fagmentary material.

This species is known from a variety of habitats such as dry sclerophyll forest and woodland, arid shrubland and heath, at altitudes of $290-1150 \mathrm{~m}$. This species has almost exclusively been labelled as $P$. thymoides, an incorrect name for $P$. hirtellus sensu stricto, (see above). Phyllanthus occidentalis is similar to P. hirtellus, in which it has been included by, for example, James and Harden (1990). The diagnostic features of P. occidentalis are very stable; however, around Black Mountain in the A.C.T. and the Coonabarabran area of New South Wales, some plants have a form that approaches that of $P$. hirtellus, i.e. possessing wider, less revolute leaves and less dense indumentum.

1j. Phyllanthus microcladus Muell. Arg., Linnaea 34: 71 (1865).

Phyllanthus microcladus var. puberulus Muell. Arg., Linnaea 34: 71 (1865).

Type: In Nova Hollandia orientali ad Clarence River, Beckler s.n. (holo G-DC; probable iso MEL n.v.).

Sauropus albiflorus subsp. microcladus (Muell. Arg.) Airy Shaw, Kew Bulletin 35: 672 (1980).

Phyllanthus microcladus var. microphyllus Muell. Arg., Linnaea 34: 72 (1865).

Type: In Nova Hollandia orientali ad Moreton-Bay, 1863, F. Mueller s.n. (holo G-DC; probable iso MEL n.v.).

Phyllanthus pusillifolius S. Moore, J. Linn. Soc. Bot. 45: 216 (1920)

Type: Queensland, Broad Sound, R. Brown [distribution no.] 3601 (BM, fragment of BM specimen: BRI, K).

Table 1: Comparison of selected characters of Phyllanthus hirtellus and P. occidentalis (measurements in $\mathrm{mm}$ ).

Phyllanthus hirtellus

Lamina margins

Lamina width

Lamina indumentum

Male pedicel length

Female sepal length

Female sepals

Filaments

Seed colour

Habit usually flat, or recurved

\section{$1.8-6.6$}

scabrous to hirsute

$0.6-1.8$

1.1-3.5

glabrous to hirsute

connate basally

yellow- to pallid brown or black

weakly erect

\section{Phyllanthus occidentalis}

usually revolute, or strongly recurved

$0.5-3.4$

puberulous to pubescent

$0.7-2.8$

$0.7-2.3$

puberulous, pubescent or pilose

variously connate

red-brown to purple

dense and compact 
Phyllanthus sp. 1, Stanley in T.D. Stanley \& E.M. Ross, Flora of South-eastern Queensland 1: 429 (1983).

[Sauropus albiflorus auct. non (Muell. Arg.) Airy Shaw; Henderson \& Forster, Queensland Vascular Plants: Names and Distribution 116 (1993), p.p.]

Illustrations: Stanley in T.D. Stanley \& E.M. Ross, Flora of South-eastern Queensland 1: 430, fig. 670 (1983); Williams et al., Trees and Shrubs in Rainforests of New South Wales and Southern Queensland: 99 (1984) as Sauropus albiflorus subsp. microcladus; James \& Harden in G.J. Harden (ed.), Flora of New South Wales 1: 399 (1990) as S. albiflorus subsp. microcladus; Hauser, Fragments of Green: 158 (1992).

Distribution: Phyllanthus microcladus is known from two widely disjunct populations. The main population occurs on the coast and hinterland of south eastern Queensland and the north eastern coast of New South Wales. The second location is near Cairns in north Queensland. This species occurs mainly in rocky places along creek and river banks in rainforest.

Notes: when describing Phyllanthus microcladus and its two varieties, Mueller Argoviensis (see above) did not cite any specimens under the base name. Both varieties conform to the description of this morphologically variable species. Variety puberulus describes the common form of this species and we here select it over var. microphyllus in order to allocate a type to the species.

1k. Phyllanthus tenellus Roxb., Fl. Indica 3: 668 (1832).

Type citation: [India:] 'Introduced from Mauritius in 1802'.

Type: India: Botanic Gardens, Calcutta, Wallich 7892A p.p. (holo K n.v., NSW microfiche).

Phyllanthus brisbanicus F.M. Bailey, Queensland Flora 5: 1418 (1902).

Type: Brisbane, Bailey (holo BRI; iso K).

Illustrations: Bailey, The Weeds and Suspected Poisonous Plants of Queensland: 178, fig. 316 (1906) as P. brisbanicus; Bailey, Comprehensive Catalogue of Queensland Plants: 475, fig. 463 (1909) as P. brisbanicus; Webster, Brittonia 22: 45, fig. 1 \& 2, 46, fig. 5 \& 6 and 47, fig. 18 (1970); Stanley in T.D. Stanley \& E.M. Ross, Flora of South-eastern Queensland 1: 430, fig. 67J (1983); James \& Harden in G.J. Harden (ed.), Flora of New South Wales 1: 398 (1990); Kleinschmidt, Suburban Weeds, edn 2, 32 (1991).

Notes: the description of P. tenellus given by James and Harden (1990) requires minor amendment. The stamen number given by them is five; however, the species commonly varies between four and six. Western Australia and the Northern Tablelands of New South Wales should be added to the recorded distribution of this species. For illustrations and further synonomy, see Webster (1970).

\section{Key to New South Wales species of Phyllanthus}

1 Branch leaves mostly scale-like (i.e. with phyllanthoid branching, though plants of P. lacunarius may have about half their branch leaves with well developed laminas).

2 Sepals 5, or if 6 then stamens 4-6

3 Branchlets flattened; stamens 3, filaments connate; female flowers solitary; styles notched; seeds striate

P. amarus 
$3^{*}$ Branchlets rounded; stamens 4-6, filaments free; female flowers 1-5; styles divided for half or more of their length; seeds granulate P. tenellus

2* Sepals 6 and stamens 3

4 Herbs to $0.3 \mathrm{~m}$ tall; stipules cream to yellow-brown; male sepals red; female pedicels at anthesis $0.2-1 \mathrm{~mm}$ long, in fruit $1-3 \mathrm{~mm}$ long; seeds striate

P. lacunarius

$4^{*}$ Shrubs to $3 \mathrm{~m}$ tall; stipules red-brown; male sepals white, yellow or green; female pedicels at anthesis 1.4-15 $\mathrm{mm}$ long, in fruit 2.2-18 $\mathrm{mm}$ long; seeds smooth, not striate

5 Branchlets rounded, not ribbed, papillate; lamina concave, with thickened margins; male sepals papillate; female pedicels $5-18 \mathrm{~mm}$ long; fruit 2.3-2.5 mm long

P. microcladus

$5^{*}$ Branchlets angular to flattened, ribbed, smooth; lamina convex to flat, with margins not thickened; male sepals smooth; female pedicels 2.2-5 $\mathrm{mm}$ long; fruit 1.8-2.2 $\mathrm{mm}$ long

P. similis

$1^{*}$ Branch leaves laminate or reduced in size (i.e., with sub-phyllanthoid branching)

6 Plants monoecious; stipules $0.3-1.6 \mathrm{~mm}$ long, red to black; leaves 3-11 mm long

7 Leaves usually flat or with recurved margins, 1.8-6.6 mm wide, with long scattered hairs mainly on the margins and midvein; weak shrubs. Mainly coastal and eastern parts of the Tablelands P. hirtellus

$7^{*}$ Leaves usually revolute or strongly recurved, $0.5-3.5 \mathrm{~mm}$ wide, with a dense covering of short hairs; dense compact shrub. Mainly western side of the Tablelands and on the Western Slope P. occidentalis

$6^{*}$ Plants dioecious; stipules $0.5-4.1 \mathrm{~mm}$ long, cream, red-brown, yellow brown or red; leaves $4.2-57.8 \mathrm{~mm}$ long

8 Seeds distinctly granulate to tuberculate

9 Leaves 13.5-32.7 mm long, margins not thickened, veins prominulous; female sepals in fruit $0.9-2 \mathrm{~mm}$ wide; filaments connate; styles notched

P. maderaspatensis

9* Leaves 4.2-19.5 mm long, margins thickened, veins not prominulous; female sepals in fruit $0.3-0.7 \mathrm{~mm}$ wide; filaments free; styles divided for half or more of their length

P. virgatus

$8^{*}$ Seeds rugose, striate or smooth

10 Plants densely hairy or at least glabrescent

11 Branchlets rounded in cross-section; stipules $0.5-1.7 \mathrm{~mm}$ long; male flowers 1-3 per axil; male sepals pubescent; male pedicels 0.2-2 mm long; female sepals in fruit $1.6-5.5 \mathrm{~mm}$ long, 1-5.3 $\mathrm{mm}$ wide, enlarging and enclosing fruit; hilum not distinctly bordered

P. carpentariae

$11^{*}$ Branchlets elliptic to rounded in cross-section; stipules $0.8-3.2 \mathrm{~mm}$ long; male flowers 1-7 per axil; male sepals glabrous to papillose; male pedicels 1.5-5.5 mm long; female sepals $1.1-3.6 \mathrm{~mm}$ long, in fruit 1-2.6 mm wide; not enlarging and enclosing fruit; hilum distinctly bordered

P. fuernrohrii

$10 *$ Plants glabrous, rarely scabrous to papillose 
12 Branchlets ribbed

13 Branchlets rounded in cross-section; stipules 0.6-1.4 mm long; leaves 5.5-18 mm long, with apex obcordate to emarginate; male pedicels $0.3-1 \mathrm{~mm}$ long; female pedicels in fruit $0.8-1.7 \mathrm{~mm}$ long; seeds with extra-hilar depression P. lacunellus

$13 *$ Branchlets angular to flattened in cross-section; stipules 1.1-5.2 $\mathrm{mm}$ long; leaves $6.6-57.8 \mathrm{~mm}$ long, apex acuminate to acute; male pedicels 1.2-6.3 mm long; female pedicels in fruit 1-7.8 $\mathrm{mm}$ long; seeds without extra-hilar depression

14 Stipules cream to yellow-brown, with bases truncate to obtuse; lamina veins prominulous, lamina margins smooth; female pedicels at anthesis $0.3-1.3 \mathrm{~mm}$ long; fruit 1.1-2.1 $\mathrm{mm}$ long; column $0.3-0.8 \mathrm{~mm}$ long; seeds $0.8-1.7 \mathrm{~mm}$ long

P. lacerosus

$14^{*}$ Stipules red-brown, with bases cordate; lamina veins not prominulous, lamina margins distinctly papillate; female pedicels at anthesis 1.5-4.5 mm long; fruit 2.8-3.4 mm long; column 1.9-4.2 mm long; seeds $2-2.7 \mathrm{~mm}$ long

P. subcrenulatus

12* Branchlets not ribbed.

15 Branchlets rounded in cross-section; leaves linear to lanceolate and distinctly involute, $0.6-3.8 \mathrm{~mm}$ wide; male pedicels $0.4-2$ $\mathrm{mm}$ long

P. involutus

15* Branchlets flattened, ellipsoid or rounded in cross-section; leaves elliptic, circular, obovate or oblanceolate, flat, $2.6-20 \mathrm{~mm}$ wide; male pedicels $0.8-6 \mathrm{~mm}$ long

16 Shrub to $2.5 \mathrm{~m}$ tall; stipule apices obtuse to rounded; styles undivided; hilum not markedly depressed or bordered

P. gunnii

16 * Low shrub or herb to $0.4 \mathrm{~m}$ tall; stipule apices acute to acuminate; styles variously divided; hilum markedly depressed and bordered

P. oblanceolatus

\section{Sauropus}

2a. Sauropus rigens (F. Muell.) Airy Shaw, Kew Bull. 35: 683 (1980).

Synostemon rigens F. Muell., Fragm. 2: 153 (1858). Phyllanthus rigens (F. Muell.) Muell. Arg., Flora 47: 513 (1864). Glochidion rigens (F. Muell.) H. Eichler, Suppl. Black's Flora S. Austral., edn 2, 210 (1965).

Type: N.S.W., Ad flumen Bogan, Bowman s.n. (MEL n.v.); In tractu Mutanic [as 'Mutanie' in F. Muell., Fragm.] Range, 3 Jan 1861, Beckler; (syn G-DC, MEL: MEL 226732, MEL 226198).

Heterocalymnantha minutifolia Domin, Biblioth. Bot. 22: 313 (1927).

Type: Sandsteinhuegel der Dividing Range bei Jericho, Mar 1910, Domin s.n. (PR n.v.)

Illustrations: Airy Shaw in J.P. Jessop (ed.), Flora of Central Australia: 193, fig. 219 (1980); Cunningham et al., Plants of Western New South Wales: 462 (1981) as 'Stiff 
Spurge'; Weber in J.P. Jessop \& H.R. Toelken, Flora of South Australia 2: 767, fig. 411B (1986); James \& Harden in G.J. Harden (ed.), Flora of New South Wales 1: 399 (1990).

Distribution: this species has a sporadic distribution across inland Australia. It is most commonly found on the foot hills and peaks of the Northern Flinders Ranges of South Australia. It is also known from Tempe Downs in the Northern Territory, Longreach and the Grey Range in Queensland, and Mootwingee and Nyngan, New South Wales. Sauropus rigens does not occur in Western Australia as recorded by James and Harden (1990).

Notes: Sauropus rigens is known from arid shrubland and Triodia grasslands on rocky slopes of hills and gorges. Some distinct geographical variation is noted and is probably due to populations being so disjunct. The Nyngan population is entirely glabrous. All other populations are hairy. Specimens from populations near Longreach possess longer than usual pedicels in both male and female flowers.

2b. Sauropus hirtellus (F. Muell.) Airy Shaw, Kew Bull. 35: 677 (1980).

Synostemon hirtellus F. Muell., Fragm. 3: 89 (1862); Phyllanthus hirtellus (F. Muell.) Muell. Arg. in DC., Prodr. 15: 326 (1866), nom. illeg. non Muell. Arg. (1863); Glochidion hirtellum (F. Muell.) H. Eichler, Suppl. Black's Flora S. Austral., edn 2, 210 (1965).

Type: In Nova Hollandia orientali tropica prope, [Queensland], Walloon, Bowman (syn MEL, K).

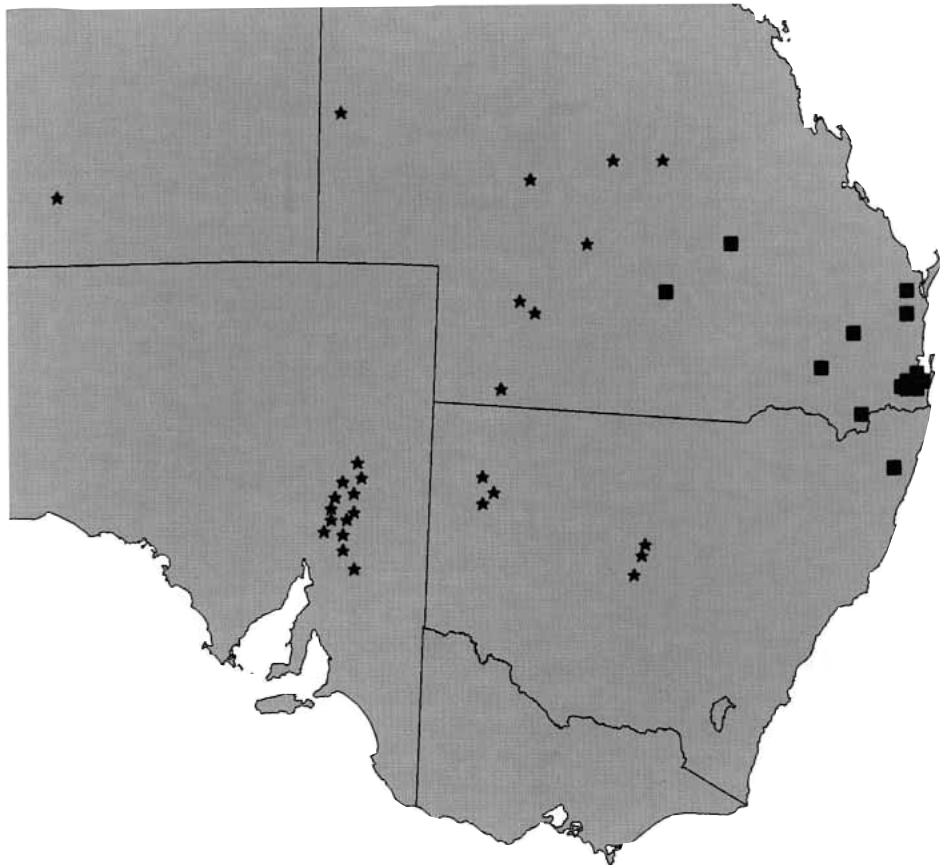

Fig. 4. Distribution of Sauropus hirtellus $₫$ and S. rigens $₫$. 
Phyllanthus thesioides Benth., Fl. Austr. 6: 98 (1873), nom. illeg. non Muell. Arg.; Glochidion thesioides H. Eichler, Suppl. Black's Flora S. Austral., edn 2, 210 (1965); Sauropus thesioides (H. Eichler) Airy Shaw, Kew Bull. 35: 684 (1980).

Type: Queensland: near Brisbane, C. Prentice (syn BRI, K).

Illustrations: Stanley in T.D. Stanley \& E.M. Ross, Flora of South-eastern Queensland 1: 430, fig. 67A \& N (1983); James \& Harden in G.J. Harden (ed.), Flora of New South Wales 1: 400 (1990).

Distribution: this species has a very restricted distribution, primarily in south-eastern Queensland, from Emerald to Maryborough and south to Mitchell, Warwick and Coolangatta. One record is also known from near Lismore on the North Coast of New South Wales (Fig. 4).

Notes: habitat information for S. hirtellus on herbarium labels is sparse, but indicates that the species has been found in grassy woodland and temperate grassland. Few herbarium specimens of $S$. hirtellus have been made, with most of those collected last century or early this century. The majority of these are from what is now suburban Brisbane. The record from New South Wales is based on a single collection in 1965. It is possible that $S$. hirtellus is extinct in New South Wales and probably under threat of extinction in Queensland. For these reasons, we suggest an initial ROTAP coding of 3EC-QN (Briggs \& Leigh 1996) for this species. James and Harden (1990) used the single New South Wales specimen to describe the species as Sauropus sp. A.

The nomenclature of this species is somewhat confused. Sauropus hirtellus, which was originally described by Mueller as Synostemon hirtellus, was later transferred to Phyllanthus Muell. Arg. as P. hirtellus (F. Muell.) Muell. Arg., the latter is an illegitimate name being a later homonym of $P$. hirtellus Muell. Arg., applicable to a different species (see above). Synostemon hirtellus was then transferred to Glochidion as G. hirtellum by Eichler and later to Sauropus as S. hirtellus by Airy Shaw.

Further complications occur with Phyllanthus thesioides Benth. whose name is illegitimate as it is a later homonym of $P$. thesioides Muell. Arg. Bentham's species was 'transferred' to Glochidion as G. thesioides by Eichler (1965), with the epithet being treated as published from this date (I.C.B.N. Art 58.1), and later to Sauropus as S. thesioides by Airy Shaw (1980). The difference between Sauropus thesioides and S. hirtellus appears to be minor; the former has glabrous leaves and stems, while the later is scabrous.

A second syntype of Phyllanthus thesioides Benth. (see above), namely 'New South Wales: Lachlan River, L. Moreton' (MEL 1595449), is inconsistent with its protologue description and is here excluded; this specimen is placed in Sauropus ramosissimus.

The key to the Sauropus by James and Harden (1990, p. 399) should be amended as follows:

4 Leaves oblong or ovate to lanceolate, thin-textured, with margins flat; seeds deeply sculptured

S. trachyspermus

$4^{*}$ Leaves linear or obovate to oblanceolate, relatively thick, with margins recurved to revolute and thickened; seeds rugose with a longitudinal rib on one side. 


\section{Acknowledgments}

We thank the heads of the following herbaria for the loan of specimens: A, AD, BM, BRI, CANB, CBG, DAV, DNA, GH, HO, K, MEL, NSW, PERTH, QRS. Thanks also to the heads of A, BM, BRI, CANB, CBG, DNA, G, GH, K, LINN, MBA, MEL, NSW, QRS for access to facilities and specimens, and the heads of $\mathrm{BM}$ and $\mathrm{K}$ for photographs of types; Clyde Dunlop and Judy Egan (DNA) for assistance with field work; Grady Webster (DAV) for helpful comments, Rod Henderson (BRI) for invaluable referee's comments, and Peter Wilson (NSW) for useful comments and editorial advice; Lyn Craven (CANB) and Frances Quinn (NE) for the Latin descriptions; David Mackay (NE) for the botanical illustrations; the director of the Australian National Parks Service and the State equivalents in New South Wales, Northern Territory, Queensland and South Australia for permission to collect in service areas. This project was supported by funding from the Australian Biological Resources Study.

\section{References}

Airy Shaw, H.K. (1980) Notes on the Euphorbiaceae from Indomalesia, Australia and the Pacific. Kew Bulletin 35: 383-399.

Beadle, N.C.W. (1976) Students Flora of North Eastern New South Wales, vol. 3 (University of New England Press: Armidale).

Bentham, G. (1873) Flora Australiensis, vol. 6. (L. Reeve: London).

Briggs, J.D., \& J.H. Leigh (1996) Rare or threatened Australian Plants, revised edition. (CSIRO Publishing: Collingwood).

Dallwitz, M.J. (1980) A general system for coding taxonomic descriptions. Taxon 29: 41-46.

Dallwitz, M.J., Paine, T.A., and Zurcher, E.J. (1993) User's Guide to the DELTA System. (Division of Entomology, CSIRO: Canberra.).

Dunlop, C.R., Leach, G.J. and Cowie, I.D. (1995) Flora of the Darwin Region, vol. 2. (Conservation Commission of the Northern Territory: Darwin).

Eichler, H. (1965) Supplement to J.M. Black's Flora of South Australia, edn 2 (Government Printer: Adelaide).

Ewart, J.E. \& Davies O.B. (1917) The Flora of the Northern Territory. (Minister for Home and Territories: Melbourne).

Forster, P.I. \& Henderson, R.J.F. (1994) Euphorbiaceae. P. 119 in R.J.F. Henderson (ed.), Queensland Vascular Plants: Names and Distribution. (Queensland Department of Environment and Heritage: Brisbane).

Hunter, J.T. \& Bruhl, J.J. (1996) Three new species of Phyllanthus (Euphorbiaceae) in South Australia. Journal of the Adelaide Botanic Gardens 17: 127-36.

James, T.A. \& Harden, G.J. (1990) Euphorbiaceae. pp. 389-430 in G.J. Harden (ed.), Flora of New South Wales, vol. 1. (New South Wales University Press: Kensington).

Moore, C. \& Betche, E. (1893) Handbook of the Flora of New South Wales. (Government Printer: Sydney).

Stanley, T.D. (1983) Euphorbiaceae. pp. 406-439 in T.D. Stanley \& E.M. Ross (eds), Flora of southeastern Queensland, vol. 1. (Queensland Department of Primary Industries: Brisbane).

Stearn, W.T. (1992). Botanical Latin. Edn 4 (David \& Charles: Melksham).

Weber, J.Z. (1986) Euphorbiaceae. pp. 735-768 in J.P. Jessup \& H. Toelken (eds) Flora of South Australia. vol. 2. (Government Printer: Adelaide).

Webster, G.L. (1956) Studies of the Euphorbiaceae, Phyllanthoideae. II. The American species of Phyllanthus described by Linnaeus. Journal of the Arnold Arboretum. 37: 1-14.

Webster, G.L. (1970) A revision of Phyllanthus (Euphorbiaceae) in the continental United States. Brittonia 22: 44-76.

Wheeler, J.R. (1992) Euphorbiaceae. pp. 589-629 in J.R. Wheeler (ed.), Flora of the Kimberley Region. (Western Australian Herbarium \& Department of Conservation and Land Management: Como). 